\title{
EFFECTS OF BREADFRUIT LEAF ETHANOL EXTRACT ON IN VIVO LOWERING BLOOD GLUCOSE LEVELS
}

\author{
Herlina Herlina*, Annisa Amriani, Dina Permata Wijaya, Filla Nur \\ Oktriliansih
}
Department of Pharmacy, Faculty of Mathematics and Natural Sciences, Sriwijaya University
Jl. Raya Palembang-Prabumulih Km. 32, Indralaya, Sumatera Selatan, 30662, Indonesia

*Corresponding author: Herlina (rinaafdil@gmail.com)

| Received: 17 March 2021

ARTICLE HISTORY

Revised: 24 December 2021
| Accepted: 11 January 2022

\begin{abstract}
Breadfruit plant is traditionally used as a medicine for diabetes mellitus. Research has been conducted on the effects of ethanol extract of breadfruit leaves (Artocarpus altilis) against a decrease in the blood glucose levels of diabetic rats induced by allocation at a dose of $130 \mathrm{mg} / \mathrm{kg} \mathrm{bb}$. Breadfruit leaf ethanol extract (BLEE) is given orally at doses of 50,100 , and $200 \mathrm{mg} / \mathrm{kg} \mathrm{BW}$ for 20 days. The test was conducted by measuring the blood glucose levels of rats with the GOD-PAP method. The observed parameters are blood glucose levels, ED 5,0 and pancreatic histopathology. The results showed a percentage decrease in blood glucose levels of $38,785 \%, 39,918 \%$, and $44,925 \%$ of BLEE with successive doses of 50,100 , and $200 \mathrm{mg} / \mathrm{kg}$ BB that had significantly differences between groups $(p<0.05)$. From the data obtained it can be concluded that BLEE 200 $\mathrm{mg} / \mathrm{kg}$ BW has a decreased activity of blood glucose levels in which the pancreatic histopathology shows the improvement of endocrine cells islets of Langerhans almost perfect. Based on the percentage relationship of decreased blood glucose levels to dose, the effective dose $\left(E D_{50}\right)$ of BLEE is $329,341 \mathrm{mg} / \mathrm{kg} \mathrm{BW}$.
\end{abstract}

Key words: alloxan, breadfruit leaves, decreased blood glucose levels, $E D_{50}$

\section{Introduction}

Diabetes mellitus (DM) is a chronic metabolic disorder due to a decrease in the function of the pancreas in producing the hormone insulin or the body cannot use the hormone insulin produced. This condition is potential to cause hyperglycemia. ${ }^{1}$ This is caused by the pancreas not producing insulin in a sufficiently large amount. ${ }^{2}$

DM therapy can be done medically by administering insulin injections and oral antidiabetic drugs (ADO). The use of insulin pharmacology therapy is relatively difficult and expensive, and the side effects arising from long-term use of ADO trigger people to prefer the use of traditional medicine as an alternative to DM therapy. ${ }^{3}$ One of the medicinal plants that have the potential to be developed as a DM pharmacological therapist traditionalist is the breadfruit plant in the leaf section. 
Leaves of breadfruit (Artocarpus altilis) is one of the traditional medicine that has been widely known to the people of Indonesia. People use the leaves of breadfruit for the treatment of people who have symptoms of polyuria due to diabetes. Breadfruit leaves contain many potent chemical compounds such as saponins, tannins, and flavonoids. ${ }^{4}$ In addition to these compounds, the breadfruit leaf also contains polyphenols, hydrocyanic acid, acetylcholine, riboflavin, and phenol. The content of flavonoids in the breadfruit leaves can be used as an antidiabetic nutritious substance for lowering blood sugar levels. These flavonoids can inhibit damage to Langerhans islet cells of the pancreas.

Research on the effectiveness of extracts of leaves of breadfruit (Artocarpus communis Forst) as antidiabetic showed that the percentage of the highest effectiveness contained in breadfruit leaf extract at a dose of $100 \mathrm{mg} / \mathrm{kg} \mathrm{BW}$ that equal to $66.77 \% .{ }^{5}$ It is necessary to conduct further research on lowering blood glucose levels of ethanol extract of leaves of breadfruit on the species (Artocarpus altilis) against strains Wistar rats induced alloxan and instantly see the picture of the rat pancreatic histopathology.

Based on the description above, an in vivo study will be conducted to reduce the blood glucose levels of alloxan-induced rats using ethanol extract of breadfruit leaves. Measurement of blood glucose levels will be analyzed using the spectrophotometric method with the reagent kit Glucose Oxidaxe Phenol-Aminophenazone Proxida Peroxidase AP). This study is expected to provide information in the form of the percent reduction in blood glucose levels, Area under Curve (AUC), effective dose (ED50) and, histopathological forms of the pancreas in Wistar strain-induced white rats.

\section{Methods}

\section{Materials}

This study uses the leaves of the plant botanicals breadfruit (Artocarpus altilis). The plant was taken in the indralaya area, South Sumatra. Determination of breadfrui carried at the Laboratory of the Plant Conservation Center of the Purwodadi Botanicall Gardens (LIPI), Purwodadi, Pasuruan, East Java. This material used $96 \%$ ethanol (Brataco®), insulin hormone, GOD-PAP kit (Diasys ${ }^{\circledR}$ ), standard glucose (Dialab®), CMC Na 0.5\% $\left(\right.$ Brataco $\AA$ ), distilled water $\left(\right.$ Brataco $\AA$ ), Na citrate (Emsure ${ }^{\circledR}$, citric acid (Emsure $\AA$ ), Dragendorff reagent, Mayer reagent, Wagner reagent, Mg Metal, AICI3 (Emsure ${ }^{\circledR}$ ), $\mathrm{FeCl} 3$ (Emsure $\left.{ }^{\circledR}\right)$, and $\mathrm{HCl}$ (Emsure $\left.{ }^{\circledR}\right)$.

The tools used in this study include, a volumetric flask (Pyrex®), a funnel glass (Pyrex®), flask, glass stirrer and other laboratory glassware (Pyrex® and Iwaki $\left.{ }^{\circledR}\right)$, a light microscope (Olympus $\left.{ }^{\circledR}\right)$, DTN-410 photometer (Dialab®) centrifugation with a speed of $2500 \mathrm{rpm}$ (IEC®), micropipette $10 \mathrm{~mL}, 100 \mathrm{~mL}$ and $1000 \mathrm{~mL}$ (Eppendorf®, Accumax®, and Labopette $\AA$ ), pipette hematocrit (Nesco $\AA$ ), analytical balance (Ohaus $\AA$ ), maceration equipment such as containers maceration, rotary evaporator (IKA®), sonde, a set of test animal care, surgical equipment rats.

\section{Making the Breadfruit Leaf Ethanol Extract}

$1 \mathrm{~kg}$ of simplicia powder macerated with $96 \%$ ethanol solvent in a closed vessel and protected from light for $1 \times 24$ hours, the pulp was remunerated with $96 \%$ ethanol 2 times. The macerate obtained is then filtered with filter paper. The concentration of the extract was carried out with a rotary evaporator at $50^{\circ} \mathrm{C}$ until thick extracts were obtained.

\section{Phytochemical Screening}

Phytochemical screening was conducted to determine the content of secondary metabolites and the class of compounds contained in karamunting fruit. Phytochemical screening is carried out, namely screening for flavonoids, alkaloids, saponins, phenolics, tannins, terpenoids, and steroids 


\section{Antihyperglycemic Activity Test}

36 white male Wistar rats were grouped randomly into 6 groups. The method of sampling is based on calculations with the Federer equation. The first step taken was to measure the blood glucose level of rats on day 0 (blood glucose before induction of alloxan). The rat fasts for \pm 18 hours. Blood sampling is carried out through the retroorbital vein plexus and collected in a non-EDTA vacutainer tube then the sample is centrifuged for 15 minutes at $2500 \mathrm{rpm}$ pmget the serum. The $10 \mu \mathrm{L}$ serum was reacted with a $1 \mathrm{~mL}$ GOD-PAP reagent. Then incubate 1 for 0 minutes at $25-30^{\circ} \mathrm{C}$. Furthermore, measurements were carried out using a DIAB DTN-410-K photometer at a maximum speed of $500 \mathrm{~nm}$.

Furthermore, 36 of these mice were induced by $130 \mathrm{mg} / \mathrm{kg}$ alloxan except for the normal group intraperitoneal. Interval of three days the glucose level was measured with a glucose strip up to the blood glucose level with the constant $\pm 200 \mathrm{mg} / \mathrm{dL}$, the rats are considered to have diabetes. Furthermore, 36 rats were divided into 6 groups of treatment as follows:
a. Normal control : without treatment.
b. Negative control : only given $0.5 \% \mathrm{NaCMC}$ suspension.
c. Positive control : given Insulin $1 \mathrm{IU} / \mathrm{kg} \mathrm{BW}$.
d. Group I : BLEE $50 \mathrm{mg} / \mathrm{kg} \mathrm{BW}$.
e. Group II : BLEE $100 \mathrm{mg} / \mathrm{kgBW}$.
f. Group III : BLEE $200 \mathrm{mg} / \mathrm{kg} \mathrm{BW.}$

Furthermore, after the rats were declared to have diabetes mellitus, the activity test with the above treatment was conducted for 20 days. Blood glucose levels were measured at intervals of 5 days; $5,10,15$, and 20 . On the 20th day, one of the mice from each treatment group was sacrificed to observe the histopathology of the mouse's pancreatic organs. After all data is obtained, the data is analyzed and processed and the

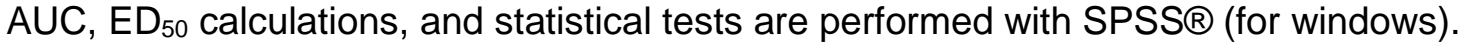

\section{Data Analysis}

Quantitative statistical analysis is done by comparing data on a decrease in blood glucose levels in the group treated with the positive control group. The initial analysis of the data reduction of blood glucose levels with descriptive normality test (Shapiro-Wilk) to assess normally distributed data. If the data are normally distributed, parametric statistical analysis is carried out by one-way ANOVA with a 95\% confidence level. The results of the analysis show that there are significant differences continued with the LSD post hoc test.

\section{Result}

Table 1. Phytochemical Screening Result of BLEE

\begin{tabular}{lc}
\hline Secondary Metabolites & Result of BLEE \\
\hline Flavonoids & + \\
Alkaloids & - \\
-Wagner & - \\
-Mayer & - \\
-Dragendorff & + \\
Saponins & + \\
Phenolics & + \\
Tannins & - \\
Terpenoids & + \\
Steroids &
\end{tabular}




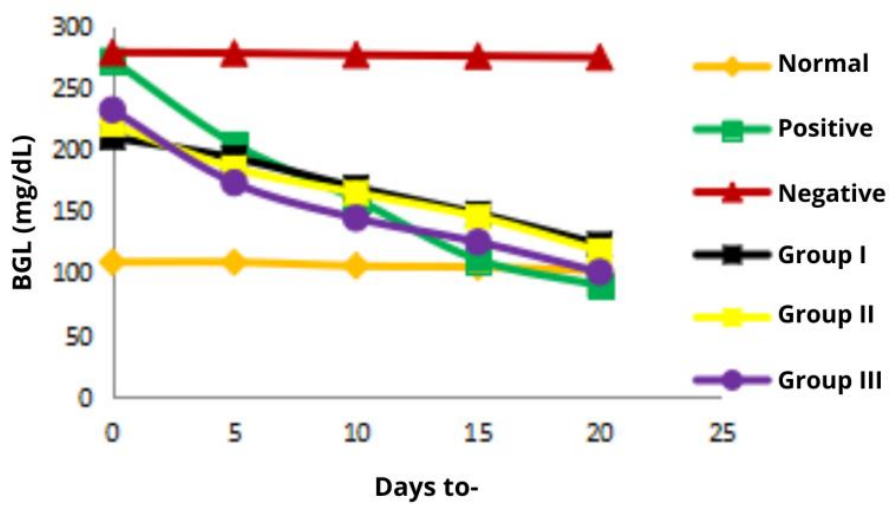

Figure 1. Graph relations average blood glucose levels for each group after induction alloxan except for fort the normal group

Table 2. Average $\mathrm{AUC}_{0-20}$ and \%DBGL

\begin{tabular}{ccc}
\hline Group & AUC $_{\mathbf{0 - 2 0}}$ & \% DBGL \\
\hline Normal & 2126.949 & - \\
Negative & 5532.946 & 0 \\
Positive & 3282.205 & 40.679 \\
Group I & 3387.015 & 38.785 \\
Group II & 3326.958 & 39.918 \\
Group III & 3047.300 & 44.925
\end{tabular}

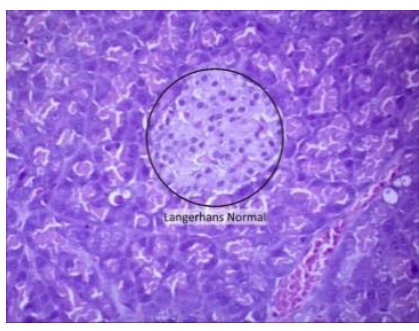

A

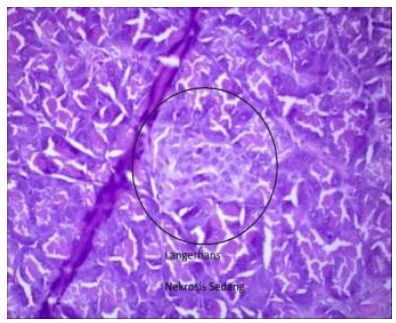

D

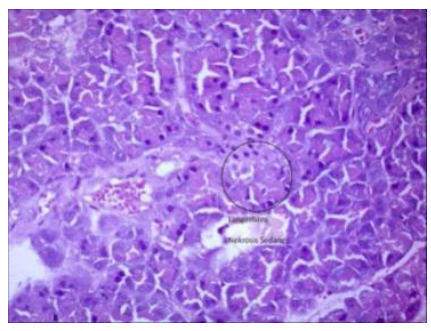

B

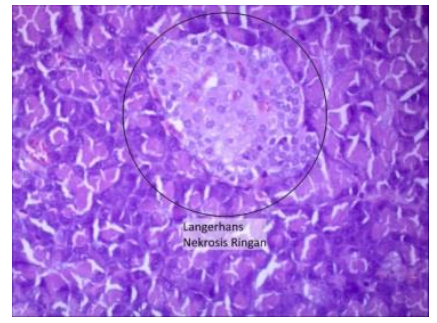

E

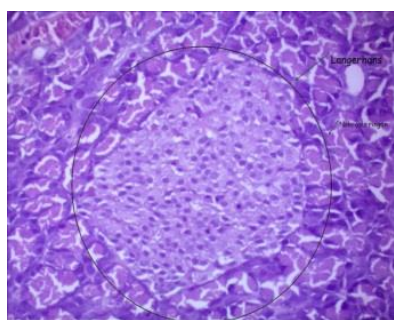

C

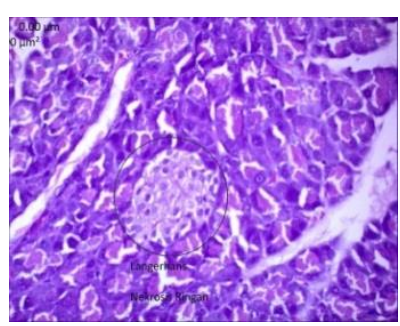

$\mathrm{F}$
Noted : A. Normal Control D. BLEE $50 \mathrm{mg} / \mathrm{kgBW}$
B. Negative Control E. BLEE $100 \mathrm{mg} / \mathrm{kgBW}$
C. Positive Control F. BLEE $200 \mathrm{mg} / \mathrm{kgBW}$

Figure 2. Histopathological HE staining islets of langerhans with a magnification of $400 x$ 


\section{Discussion}

\section{Phytochemical Screening}

Randemen percent obtained by $7.7649 \%$. The amount of value randemen extract demonstrates the effectiveness of the extraction process that is influenced by the size of the powder bulbs, the type of solvent used, and extraction time. Phytochemical screening of the results in Table 1 showed a positive reaction to the test flavonoids, steroids, phenolics, tannins, and saponins. However, a negative reaction to the testing of triterpenoids and alkaloids.

\section{Hypoglycemic Activity Test}

Based on figure 1, it can be concluded that the blood glucose level in the normal group was relatively stable did not experience significant changes below $126 \mathrm{mg} / \mathrm{dL}$. This is because the normal group of mice is not given any treatment except given the standard feed and drinks only. While the negative control group showed relatively stable blood glucose levels in DM conditions $\geq 200 \mathrm{mg} / \mathrm{dL}$ on the 0th day to the 20th day after treatment. This is because the negative control group after induction of rats alloxan was only given a $0.5 \% \mathrm{Na} C M C$ preparation which did not have antihyperglycemic activity, but only acted as a carrier so that it would not affect the reduction in rat blood glucose levels.

The positive control group based on figure 1 shows the largest decrease in blood glucose level 1 , supported by data seen from day 0 before treatment and after treatment on day 20. This is because after the induction of alloxan insulin injections is given, it can reduce rat blood glucose levels. Insulin with a dose of $1 \mathrm{IU} / \mathrm{kg} \mathrm{BW}$ given subcutaneously. Insulin preparations were chosen in therapy for positive control because insulin is the first-line therapy for patients with type $1 \mathrm{DM}$ who have damaged pancreatic $\beta$ cells permanently by replacing insulin in the body. ${ }^{6}$ In addition, insulin works by transporting glucose into cells so that insulin intake by the body can be met and blood glucose levels can be normal in the body. ${ }^{7}$

Every time BLEE was administered for 20 days after alloxan induction there was a decrease in blood glucose levels in all treatment groups giving extracts that were previously hyperglycemic. However, the greatest decrease in blood glucose levels is at the treatment of BLEE $200 \mathrm{mg} / \mathrm{kg} \mathrm{BW}$. This is because the greater the dose of EEBM given, the greater the antihyperglycemic effect produced due to the high content of metabolites in the extract. ${ }^{8}$ In the BLEE treatment $100 \mathrm{mg} / \mathrm{kg} \mathrm{BW}$ and $50 \mathrm{mg} / \mathrm{kg} \mathrm{BW}$ also decreased where the blood glucose level was $\leq 126 \mathrm{mg} / \mathrm{dL}$ but it was not as good as the glucose level in the BLEE $200 \mathrm{mg} / \mathrm{kg} \mathrm{BW}$ treatment which was below $\leq 100 \mathrm{mg} / \mathrm{dL}$.

\section{Area Under the Curve (AUC)}

Based on table 2, the most effective dose is BLEE $200 \mathrm{mg} / \mathrm{kg} \mathrm{BW}$. Based on the above table it can be concluded that the negative control group had the greatest AUC value because it did not experience a decrease in blood glucose levels due to the absence of compounds with antihyperglycemic activity given. Whereas the smallest AUC value was owned by the BLEE $200 \mathrm{mg} / \mathrm{kg} \mathrm{BW}$, followed by positive control, the BLEE $100 \mathrm{mg} / \mathrm{kg} \mathrm{BW}$ and BLEE $50 \mathrm{mg} / \mathrm{kg} \mathrm{BW}$. So that the best reduction in glucose levels is the BLEE $500 \mathrm{mg} / \mathrm{kg} \mathrm{BW}$. The lower the AUC value of the treatment group, the better its activity in reducing blood glucose levels. ${ }^{9}$

Judging from the results of the largest percent decrease in blood glucose levels based on the table at the treatment of BLEE $200 \mathrm{mg} / \mathrm{kg} \mathrm{BW}$, followed by BLEE $100 \mathrm{mg} / \mathrm{kg}$ BW and $50 \mathrm{mg} / \mathrm{kg}$ BW. Because the AUC value is inversely proportional to the antihyperglycemic activity or percent decrease in blood glucose levels. This is in line with research, where the highest dose of melinjo seed infusion, which is $50 \%$, can provide the highest glucose levels from the $25 \%$ infusion given. ${ }^{10}$ When compared with the 
negative control group there are differences. Where the negative control group did not provide a decrease in blood glucose levels because the treatment was not given any compound with antihyperglycemic activity.

When compared with the positive control, the biggest decrease in blood glucose level is BLEE $200 \mathrm{mg} / \mathrm{kg} \mathrm{BW}$. But basically according to the study, insulin must have a better effect than the extract given ${ }^{7}$. This is because insulin only works to transport glucose into cells so that in irregular and inappropriate uses the blood glucose level will still be higher. In contrast, the flavonoids contained in the extract play a role in regenerating pancreatic $\beta$ cells so that pancreatic $\beta$ cells will be able to secrete insulin well again. ${ }^{11}$ So that the best AUC and \% DBGL with antihyperglycemic activity is the BLEE $200 \mathrm{mg} / \mathrm{kg} \mathrm{BW.}$

After calculating the AUC value and \% DBGL, it is continued with the calculation of the ED50 value by comparing the dose value used with the \% DBGL. Effective dose (ED50) is a dose of extract that can cause a therapeutic effect in $50 \%$ of individuals. ${ }^{12}$ This calculation is done to find out what dose can cause the effect of reducing high blood glucose levels in $50 \%$ of experimental animals. Based on calculations, the ED50 value of $329,341 \mathrm{mg} / \mathrm{kg} \mathrm{BW}$ was obtained. So it can be concluded that the antihyperglycemic activity achieved in this study with a sample in the form of BLEE has a low activity where the resulting ED50 value is far from the largest dose used is $200 \mathrm{mg} / \mathrm{kg} \mathrm{BW}$.

Data on decreased blood glucose levels obtained in each group were then statistically analyzed using the SPSS program. The first analysis carried out was a normality test on the value of blood glucose levels and body weight of rats. The results of the normality test from the two data above use the Shapiro-Wilk method on rat blood glucose levels and body weight of rats each group is normally distributed ( $p>0.05)$.

Data analysis is then continued by analyzing whether there are differences between the two paired variables or the statistical t-test pairing between groups. From the results of paired intergroup tests on blood glucose levels before and after induction, there were significant differences in the positive, negative, the dose $50 \mathrm{mg} / \mathrm{kg} \mathrm{BW}$, the dose 100 $\mathrm{mg} / \mathrm{kg} \mathrm{BW}$, and the dose $200 \mathrm{mg} / \mathrm{kg} \mathrm{BW} \mathrm{(} \mathrm{<0.05).} \mathrm{This} \mathrm{can} \mathrm{be} \mathrm{interpreted} \mathrm{that} \mathrm{giving}$ alloxan can make rats become hyperglycemia, whereas in the normal group there is no significant difference. This is because in the normal group the test animals are not given treatment.

Subsequent analysis was carried out with one-way ANOVA statistical analysis with a $95 \%$ confidence level. The one-way ANOVA parametric statistical value of AUC0-20 and\% PKGD values showed that there were significant differences between groups ( $p$ $<0.05$ ). According to the study, one-way ANOVA parametric statistical analysis is used to analyze variability or diversity of data into two sources of variation (within and between $)^{13}$.

Statistical testing was continued with the post hoc least significant differences (LSD) test because in the ANOVA test there was a significant difference between groups. The post hoc LSD test was used as a follow-up test of a one-way ANOVA, namely to see significant similarities or differences in data on decreasing blood glucose levels between groups. ${ }^{13}$

The results of the post hoc LSD $\mathrm{AUC}_{0-20}$ test analysis and the value of \% DBGL showed that there were significant differences $(p<0.05)$ between treatment groups with a dose of $50 \mathrm{mg} / \mathrm{kg} \mathrm{BW}$, a dose of $100 \mathrm{mg} / \mathrm{kg} \mathrm{BW}$ and a dose of $200 \mathrm{mg} / \mathrm{kg} \mathrm{BW}$. This shows that giving different doses will give different results to the decrease in blood glucose levels. The results of the analysis on positive control did not show a significant difference ( $p>0.05$ ) with the treatment group dose $50 \mathrm{mg} / \mathrm{kg} \mathrm{BW}$ and $100 \mathrm{mg} / \mathrm{kg} \mathrm{BW}$, but there were significant differences $(p<0.05)$ to the treatment group dose $200 \mathrm{mg} / \mathrm{kg} \mathrm{BW}$. This shows that the ethanol extracts of melinjo seeds 50 and $100 \mathrm{mg} / \mathrm{kg} \mathrm{BW}$ can provide a decrease in blood glucose levels the same as administering insulin which can reduce blood glucose levels. Whereas with group d ethanol extract a dose of $200 \mathrm{mg} / \mathrm{kg}$ gives a 
significant difference to the administration of insulin. This is because the dose of 200 $\mathrm{mg} / \mathrm{kg} \mathrm{BW}$ is better in reducing glucose levels compared with positive controls.

\section{Histopathology Pancreas}

Histopathological observation of pancreas in white Wistar male rats in each treatment group was carried out using the Hematoxylin-Eosin staining method to see the shape of the island of Langerhans. One mouse was sacrificed in each group to observe the pancreas after treatment for 20 days. Rats taken from their pancreatic organs were selected based on the largest percentage of decrease in blood glucose level in each group. Histopathological preparations were made with hematoxylin-eosin staining. Histopathological observation of mouse pancreas was observed using a descriptive microscope with a magnification of $400 \mathrm{x}$. Histopathological observations of the rat pancreas can be observed in the image below.

Based on the description above rat pancreatic histopathology in Figure $2 \mathrm{~A}$, shows that rats of the normal control group showed a healthy pancreas condition and were not damaged. It can be seen from the order of arrangement of endocrine cells in the islets of Langerhans are spread wide and no cells undergoing necrosis. Visible cell nuclei and spherical purple with pink cytoplasm. Overview rat pancreas negative control group (Figure 2 B) shows the shape of the islets of Langerhans which necrotic tissue that can be seen from the empty space without core just look empty cytoplasm. This is due to necrosis induced by alloxan which can form reactive oxygen by removing the $\mathrm{SH}$ group which binds selectively to pancreatic $\beta$ cells that can no longer produce insulin. ${ }^{14}$

The positive control group (Figure $2 \mathrm{C}$ ) illustrates the islets of Langerhans that look smaller but still visible purple cell nuclei do not like the negative control group who lost their nuclei and still there is space without a core. This suggests that insulin administration does not repair damaged pancreatic tissue as seen from the islets of Langerhans are very small so that the number of cells is also slightly. Ethanol extract of leaves of breadfruit $50 \mathrm{mg} / \mathrm{kg} \mathrm{BW}$ in the treatment group dose I (Figure $2 \mathrm{D}$ ) shows an overview of histopathology of the pancreas that does not vary much with the negative control group that contained the empty cells with no nucleus that indicates tissue necrosis, but there are improvements to the dose I look on began their round-shaped cell nucleus is perfect, although not entirely evenly.

Ethanol extract of leaves of breadfruit $100 \mathrm{mg} / \mathrm{kg}$ in the treatment group dose II (Figure $2 \mathrm{E}$ ) showed an improvement in the islets of Langerhans with a shape more clearly and there is a cell nucleus is round, although still a bit is on the edge of the island and is no longer visible cells without nuclei. Pancreatic picture breadfruit leaf ethanol extract of the highest dose of $200 \mathrm{mg} / \mathrm{kg}$ on the third dose treatment group (Figure $2 \mathrm{~F}$ ) also showed improvement with their core in each cell and began to move up to half of the islets of Langerhans compared to the first and second dose treatment. This is possible if the dosage of ethanol extract of leaves of breadfruit larger can improve overall tissue necrosis.

Improvement of pancreatic $\beta$ cells in the treatment group the first dose, the second dose, and the third dose due to the active metabolite contained in the ethanol extract of the leaves of breadfruit flavonoid class of polyphenolic compounds that have antioxidant activity. Polyphenol compounds donate electrons to electron-deficient free radicals that can stabilize free radicals and inhibit the chain reaction of free radical formation. ${ }^{15}$ Antioxidants work by inhibiting the destruction of pancreatic $\beta$ cells utilizing free radicals generated from alloxan, other than that antioxidants can protect pancreatic $\beta$ cells are still functioning to regenerate and produce insulin. 


\section{Conclusion}

BLEE $200 \mathrm{mg} / \mathrm{kg} \mathrm{BW}$ has a decreased activity of blood glucose levels where the pancreatic histopathology shows the improvement of endocrine cells islets of Langerhans almost perfect. Based on the percentage relationship of decreased blood glucose levels to dose, the effective dose $\left(E D_{50}\right)$ of BLEE is $329,341 \mathrm{mg} / \mathrm{kg} \mathrm{BB}$.

\section{References}

1. Wells B, Dipiro J, Schwinghammer T, Dipiro C. Pharmacotherapy handbook. 9th ed. United States: Mc Graw Hill; 2015. 235-39 p.

2. Schoenfelder T, Cirimbelli T, Citadini Z. Acute effect of trema micrantha on serum glucose levels in normal and diabetic rats. J Ethnopharmacol. 2006;107:456-9. Available from: doi: 10.1016/j.jep.2006.07.027

3. Sukandar E, Andrajati R, Sigit J, Andayana I, Setiadi A, Kusnandar. ISO farmakoterapi. 1st ed. Jakarta: PT ISFI Penerbitan; 2008.

4. Hutami N. Uji potensi insektisida ekstrak daun sukun (artocarpus altilis) terhadap lalat rumah (nusca domestica) dengan metode semprot. Universitas Brawijaya; 2013.

5. Dipa. Efektifitas ekstrak daun sukun (artocarpus communis forst.) dalam menurunkan kadar glukosa darah dan mempertahankan jumlah sperma pada tikus (rattus norvegicus I.). Kampus Bukit Jimbaran; 2015.

6. Wilcox G. Insulin and insulin resistance. Clin Biochem Rev. 26AD;2005(2):19-39.

7. Piero N, Kimuni N, Ngeranwa N, Orinda O, Njagi M, Maina D, et al. Antidiabetic and safety of lantana rhodesiensis in alloxan induced diabetic rats. J Dev Drugs. 2015;4(1):2.

8. Pramewari $\mathrm{O}$, Widjanarko $\mathrm{S}$. Uji efek ekstrak air daun pandan wangi terhadap penurunan kadar glukosa darah dan histopatologi tikus diabetes melitus. J Pangan dan Agroindustri. 2014;2(2):23.

9. Chotimah C, Sutrisna E, Wahyuni A. Uji penurunan kadar glukosa darah oleh ekstrak air herba jaka tua (scoparia dulcis I.) pada kelinci jantan yang dibebani glukosa. Pharmacon. 2008;9(2):50.

10. Ira C, Cikra I. Efek farmakologi infusa biji melinjo (gnetum gnemon I.) sebagai antihiperglikemia pada mencit (mus musculus) yang diinduksi dextrosa monohidrat 40\%. J Pharm Sci Pharm Pr. 2015;2(1):27-32.

11. Afifah $\mathrm{H}$. Mengenal jenis- jenis insulin terbaru untuk pengobatan diabetes. Makal Farmasetika. 2016;1(4):2-3.

12. Departemen Farmakologi dan Terapeutik Fakultas Kedokteran Universitas Indonesia. Farmakologi dan terapi. 5th ed. Jakarta: Balai Penerbit Fakultas Kedokteran Universitas Indonesia; 2007.

13. Santoso P, Ashari. Analisis statistik dengan microsoft excel dan SPSS. Yogyakarta; 2005.

14. Nugroho A. Hewan percobaan diabetes melitus, patologi dan mekanisme aksi diabetogenetik. J Biodiversitas. 2006;7(4):380.

15. Hattenschwiler, $S$ Vitousek $P$. The role of polyphenols interrestrial ecosystem nutrient cycling. Natl Libr Med. 2000;15(6):239. 